\title{
Deep brain stimulation for appetite disorders: a review
}

\author{
Alexander C. Whiting, MD, ${ }^{1}$ Michael Y. Oh, MD, ${ }^{2}$ and Donald M. Whiting, MD ${ }^{2}$ \\ 1Department of Neurosurgery, Barrow Neurological Institute, St. Joseph's Hospital and Medical Center, Phoenix, Arizona; and \\ 2Department of Neurosurgery, Allegheny Health Network, Pittsburgh, Pennsylvania
}

\begin{abstract}
The mechanisms of appetite disorders, such as refractory obesity and anorexia nervosa, have been vigorously studied over the last century, and these studies have shown that the central nervous system has significant involvement with, and responsibility for, the pathology associated with these diseases. Because deep brain stimulation has been shown to be a safe, efficacious, and adjustable treatment modality for a variety of other neurological disorders, it has also been studied as a possible treatment for appetite disorders. In studies of refractory obesity in animal models, the ventromedial hypothalamus, the lateral hypothalamus, and the nucleus accumbens have all demonstrated elements of success as deep brain stimulation targets. Multiple targets for deep brain stimulation have been proposed for anorexia nervosa, with research predominantly focusing on the subcallosal cingulate, the nucleus accumbens, and the stria terminalis and medial forebrain bundle. Human deep brain stimulation studies that focus specifically on refractory obesity and anorexia nervosa have been performed but with limited numbers of patients. In these studies, the target for refractory obesity has been the lateral hypothalamus, ventromedial hypothalamus, and nucleus accumbens, and the target for anorexia nervosa has been the subcallosal cingulate. These studies have shown promising findings, but further research is needed to elucidate the long-term efficacy of deep brain stimulation for the treatment of appetite disorders.
\end{abstract}

https://thejns.org/doi/abs/10.3171/2018.4.FOCUS18141

KEYWORDS anorexia nervosa; appetite disorders; deep brain stimulation; neuromodulation; obesity

$\mathrm{D}$ EEP brain stimulation (DBS) has become a commonly performed, well-established surgical treatment for multiple neurological disorders, including Parkinson disease, essential tremor, and dystonia. ${ }^{34,47,60}$ Because of its low morbidity and mortality, efficacy, adjustability, and reversibility, DBS has been studied for the treatment of a variety of other diseases. ${ }^{14}$ Over the last several decades, studies of the mechanisms of development of appetite disorders, such as anorexia nervosa (AN) and obesity, have demonstrated numerous complex contributions from the central nervous system..$^{30,48}$ This evidence of central nervous system involvement led to the development of a large body of medical literature that evaluates the efficacy of DBS for the treatment of these disorders.

\section{Deep Brain Stimulation for Obesity}

The prevalence of obesity across all age spectrums has greatly increased over the last few decades in both the developed and the developing world. ${ }^{43,44,57}$ Obesity is defined as a body mass index (BMI) greater than or equal to 30 , and morbid obesity is defined as a BMI greater than or equal to 40 or greater than 35 with comorbidities. In the United States, the prevalence of obesity in adults is $35.0 \%$ in men and $40.4 \%$ in women, with $7.7 \%$ of adults meeting the criteria for morbid obesity. ${ }^{16}$ Morbid obesity is associated with a significantly impaired quality of life, multiple comorbidities, and premature death. ${ }^{16,43}$ Nonsurgical treatments for morbid obesity are associated with exceedingly high failure rates, while successful surgical options, such as gastric bypass and sleeve gastrectomy, come with significant morbidity and demonstrate considerable relapse and failure rates. ${ }^{7,9,18}$ Because of its safety profile and adjustability, DBS has emerged as a potential intervention for morbid obesity.

\section{Physiology and Targets}

Obesity is the result of an incredibly complex interplay among environmental, genetic, homeostatic, and hedonic factors. Ultimately, obesity is a problem of energy

ABBREVIATIONS AN = anorexia nervosa; BMI = body mass index; DBS = deep brain stimulation; $\mathrm{fMRI}=$ functional $\mathrm{MRI}$; $\mathrm{LH}=$ lateral hypothalamus; $\mathrm{MDD}=$ major depressive disorder; $\mathrm{NAC}=$ nucleus accumbens; $\mathrm{OCD}=$ obsessive-compulsive disorder; $\mathrm{VMH}=$ ventromedial hypothalamus.

SUBMITTED March 20, 2018. ACCEPTED April 24, 2018.

INCLUDE WHEN CITING DOI: 10.3171/2018.4.FOCUS18141. 
imbalance, with a net positive energy balance over time. Much of the control over the process of balancing energy originates within the central nervous system. ${ }^{48}$ Numerous DBS targets for obesity have been proposed; however, this review focuses on the 3 targets that have emerged as the most promising and that are the most studied: the lateral hypothalamus (LH), the ventromedial hypothalamus $(\mathrm{VMH})$, and the nucleus accumbens (NAc).

\section{Lateral Hypothalamus}

The LH is considered to be a small $(6 \times 6 \times 3.5-\mathrm{mm})$ target within the hypothalamic nuclei, lying inferior to the fornix and superoposterior to the optic nerve and chiasm..$^{52}$ The LH became classically known as the "feeding center" of the brain on the basis of several lesion studies that were performed midway through the previous century. ${ }^{55}$ These studies demonstrated that bilateral LH lesions in rats resulted in decreased food intake, weight loss, and decreased food-seeking behavior. ${ }^{2,13,26,42}$ Compared with sham-operated controls, rats with bilateral LH lesions gained significantly less weight with equal quantities of digested food, and they exhibited increased core body temperature. ${ }^{23,31}$ Subsequently, the LH was discovered to be the source of extensive projections of neurons containing 2 newly discovered neuropeptides: melanin-concentrating hormone and orexin. .50 Both neuronal populations have broad projections throughout the central nervous system, and direct injection of either melanin-concentrating hormone or orexin into the ventricles will cause rats to feed, and these levels increase in rats during periods of starvation. ${ }^{46,50}$

Multiple early animal studies demonstrated that lowfrequency stimulation of the LH resulted in an excitatory stimulation of these fibers, with animals demonstrating food-seeking and food-hoarding behavior, increased gastrointestinal blood flow, and activation of vagal pathways..$^{17,25,41}$ In 2007, Sani et al. ${ }^{51}$ reported on the use of high-frequency DBS of the bilateral LH in 16 rats that resulted in a $2.3 \%$ weight loss in stimulated rats and a $13.8 \%$ weight gain in unstimulated controls.

The first pilot study of bilateral LH DBS for obesity in humans was performed in 2013 by Whiting et al. ${ }^{61}$ (Table $\left.1^{21,22,61}\right)$. Three patients who met the criteria for morbid obesity, who had had multiple unsuccessful attempts at lifestyle modification, and in whom bariatric surgery had failed underwent stereotactic DBS electrode placement bilaterally in the LH. The study was primarily focused on safety outcomes, and no serious adverse effects were observed during the mean follow-up of 35 months. Transient nausea, anxiety, and temperature change sensations were noted during programming changes but lasted less than 5 minutes. Throughout most of this pilot study, stimulation parameters were set at a frequency of $185 \mathrm{~Hz}$ and a pulse width of $90 \mu \mathrm{sec}$. The resting metabolic rate was tested systematically using monopolar stimulation at different voltages and electrode contacts to find the optimized stimulation parameters and contacts. Although the study was primarily focused on safety, early data on weight change showed a trend toward weight loss in 2 of the 3 patients at optimized parameters. Other studies are currently being completed that examine the effect of different frequencies and pulse widths on resting metabolic rate and sleep energy expenditure, and long-term studies are examining weight changes, effects on comorbidities, and the durability of resting metabolic rate changes.

\section{Ventromedial Hypothalamus}

The VMH is a $2 \times 3 \times 5-\mathrm{mm}$ target posterior to the optic nerve, anterior to the mammillary body, and inferior to the anterior commissure. ${ }^{52}$ The $\mathrm{VMH}$ was classically referred to as the "satiety center" of the brain after animal lesion studies demonstrated that bilateral VMH lesions resulted in increased body lipid and insulin levels compared with those in controls and that bilateral VMH lesions resulted in metabolic hyperphagia and obesity. ${ }^{10,45}$ Electrical stimulation studies in rats demonstrated that low-frequency stimulation of the VMH at $60 \mathrm{~Hz}$ resulted in the disruption of feeding behavior. The results of these studies led to the design of experiments involving DBS of the VMH in animals. In one study, low-frequency DBS of the $\mathrm{VMH}(50 \mathrm{~Hz})$ in minipigs resulted in decreased weight gain over time, ${ }^{40}$ while in a separate study, intraventricular DBS electrodes were placed adjacent to the $\mathrm{VMH}$ in monkeys, and stimulation at a low frequency $(80 \mathrm{~Hz}) \mathrm{re}-$ sulted in reduced body weight and body fat ${ }^{56}$ Conversely, Laćan et al. ${ }^{35}$ found that high-frequency DBS $(185 \mathrm{~Hz})$ of the $\mathrm{VMH}$ in monkeys resulted in increased food intake.

The first report of a study of DBS in humans specifically for obesity was published in 2008 by Hamani et al., ${ }^{21}$ who treated a patient with morbid obesity (Table 1). The patient had no change in weight while undergoing highfrequency stimulation and demonstrated mild weight loss that was eventually regained while undergoing lowfrequency stimulation. Interestingly, the patient demonstrated improved memory during stimulation, prompting divergent experiments investigating DBS for Alzheimer's disease. No further studies in humans that examine DBS of the VMH for refractory obesity have been published to date.

\section{Nucleus Accumbens}

The NAc is an $8 \times 6 \times 6-\mathrm{mm}$ region of the striatum located inferior to the anterior limb of the internal capsule, anterior to the preoptic area of the hypothalamus, and superolaterally to the optic nerve. ${ }^{52}$ The NAc is functionally divided into 2 subregions: the NAc shell, with broad projections primarily to the limbic system, and the NAc core, with projections primarily to the caudate and putamen, the globus pallidus, and the substantia nigra. ${ }^{11,19}$ Both subregions of the NAc consist substantially of neurons containing dopamine receptors, and both have been associated with reward pathways, with the NAc shell associated with motivation-based reward pathways and the NAc core associated with learning-based reward pathways. ${ }^{49}$

With its complex involvement in reward, craving, anticipation, and withdrawal pathways, the NAc has emerged as a treatment target for obesity. ${ }^{27,55}$ Indeed, the effects on the NAc circuitry from excessive consumption of palatable foods are similar to the effects of drug abuse, so dysfunctional circuitry could lead to the outcomes observed with morbid obesity. ${ }^{33}$ Compared with normal-weight controls, obese patients demonstrate greater activation of the NAc and reward pathways when exposed to high-calorie foods. ${ }^{54}$ 
TABLE 1. Published reports of deep brain stimulation for the treatment of obesity in humans

\begin{tabular}{ccccccc}
\hline $\begin{array}{c}\text { Authors } \\
\text { \& Year }\end{array}$ & Pts & $\begin{array}{c}\text { No. of } \\
\text { Pts }\end{array}$ & $\begin{array}{c}\text { Study } \\
\text { Design }\end{array}$ & Target & $\begin{array}{c}\text { Stimulation } \\
\text { Parameters }\end{array}$ & Findings \\
\hline $\begin{array}{c}\text { Hamani et } \\
\text { al., 2008 }\end{array}$ & Adult w/ morbid obesity & 1 & $\begin{array}{c}\text { Case } \\
\text { report }\end{array}$ & $\begin{array}{c}\text { Ventromedial } \\
\text { hypothalamus }\end{array}$ & $\begin{array}{c}\text { Bilat, } 2.8 \mathrm{~V}, 60 \mu \mathrm{sec}, \\
130 \mathrm{~Hz}\end{array}$ & $\begin{array}{c}\text { Minimal long-term weight change; improved } \\
\text { memory }\end{array}$ \\
$\begin{array}{c}\text { Whiting et } \\
\text { al., 2013 }\end{array}$ & $\begin{array}{c}\text { Adults w/ treatment- } \\
\text { refractory obesity }\end{array}$ & 3 & $\begin{array}{c}\text { Open-label } \\
\text { trial }\end{array}$ & $\begin{array}{c}\text { Lat hypothala- } \\
\text { mus }\end{array}$ & $\begin{array}{c}\text { Bilat, variable voltage, } \\
90 \mu \mathrm{sec}, 185 \mathrm{~Hz}\end{array}$ & $\begin{array}{c}\text { No serious adverse effects; trend toward } \\
\text { weight loss in 2/3 pts }\end{array}$ \\
\hline $\begin{array}{c}\text { Harat et al., } \\
2016\end{array}$ & $\begin{array}{c}\text { Adult w/ iatrogenic } \\
\text { hypothalamic obesity }\end{array}$ & 1 & $\begin{array}{c}\text { Case } \\
\text { report }\end{array}$ & $\begin{array}{c}\text { Nucleus accum- } \\
\text { bens }\end{array}$ & $\begin{array}{c}\text { Bilat, } 3.75 \mathrm{~mA}, 208 \\
\mu s e c, 130 \mathrm{~Hz}\end{array}$ & $\begin{array}{c}\text { At 14-mo follow-up, change in BMl (from } 52.9 \\
\text { to 48.2); no major adverse effects reported }\end{array}$ \\
\hline
\end{tabular}

Pts = patients.

Early animal studies demonstrated that NAc lesions in rats resulted in abolition or severe reduction in foodhoarding behavior. ${ }^{32}$ When the rats were treated with levodopa, hoarding behavior was restored, implicating the dopaminergic NAc pathways in these feeding-related behaviors. Halpern et al. ${ }^{20}$ examined the effects of DBS of the NAc in a rat model by placing bilateral electrodes in the NAc shell. They found that high-frequency stimulation $(160 \mathrm{~Hz})$ in diet-induced obese mice resulted in acute reductions in caloric intake and induced weight loss. Their study demonstrated that this change was mediated by a change in dopamine signaling involving dopamine D2 receptors. ${ }^{20}$ Interestingly, Wu et al. ${ }^{62}$ demonstrated that mice exhibited appreciable local field potentials in the NAc during reward anticipation, such as food presentation, and that closed-loop stimulation of the NAc after the presentation of these triggers reduced binge-eating behavior.

The only published report of NAc DBS primarily for obesity in humans is a case report by Harat et al. ${ }^{22}$ describing a woman with hypothalamic obesity after craniopharyngioma surgery (Table 1). She underwent implantation of bilateral NAc DBS electrodes, followed by chronic high-frequency stimulation for 14 months, and subsequently demonstrated a change in BMI from 52.9 to 48.2 with no major adverse effects.

Although no organized trials of DBS of the NAc for obesity have been published, the NAc is already a wellstudied DBS target for obsessive-compulsive disorder (OCD), depression, and Tourette syndrome. ${ }^{20}$ In a study by Mantione et al., ${ }^{38}$ a woman had bilateral NAc DBS electrodes placed for treatment-refractory OCD and underwent high-frequency stimulation. Interestingly, the patient also demonstrated baseline nicotine addiction and obesity, but with chronic high-frequency stimulation demonstrated smoking cessation and significant weight loss. This experience highlighted the common circuitry involved in dysfunctional reward pathways and supported the feasibility of DBS of the NAc for the treatment of obesity. ${ }^{38}$

\section{Deep Brain Stimulation for Anorexia Nervosa}

$\mathrm{AN}$ is a multifaceted, challenging disease defined as a restriction of energy intake relative to bodily requirements, leading to a relatively low body weight in association with a distorted body image and anxiety about weight gain. ${ }^{1}$
Young females have the highest prevalence rates, which are estimated to be $0.3 \%$ in this population. ${ }^{28} \mathrm{AN}$ is associated with severe morbidity and mortality, and estimates in the medical literature have established $\mathrm{AN}$ as having the highest mortality rate of any psychiatric disease. ${ }^{3,24,53}$ The current mainstays of treatment involve diet and nutritional support, various forms of interventional therapy, and medical treatment of comorbidities, with patients with severe AN requiring admission to specialized inpatient units. Unfortunately, despite multiple intensive modalities of medical care and intervention, the rates of long-term treatment success and remission are relatively low., ${ }^{4,356}$ Because of the lack of consistently successful treatment strategies for $\mathrm{AN}$, its strong association as a comorbidity with other psychiatric diseases, and the adjustability and safety profile of DBS, DBS has emerged as a potential intervention for AN.

\section{Physiology and Targets}

Multiple imaging studies have demonstrated that persons with AN have dysfunctional appetitive behaviors and cerebral circuitry, related to both sensory processing and reward mechanisms. ${ }^{30}$ Cerebral blood oxygenation changes on functional MRI (fMRI) have shown that, when presented with pictures of high-calorie food, anorexic females have more extensive activation of the left insula, the anterior cingulate gyrus, and the amygdala and hippocampus compared with controls. ${ }^{12}$ Further fMRI studies demonstrated greater activation of the medial orbitofrontal and anterior cingulate cortex in anorexic individuals than in controls when presented with images of food. ${ }^{58}$ FDG PET sequences in anorexic female patients demonstrated hypermetabolism in the frontal lobe, amygdala and hippocampus, left insula, and left subcallosal gyrus and demonstrated hypometabolism in the parietal lobe compared with age-matched healthy controls. ${ }^{64}$ Because AN demonstrates many functional parallels to OCD and frequently co-occurs with it, ${ }^{8}$ similar dysfunctional circuitry and potential DBS targets have been proposed for these diseases. ${ }^{63}$ Current research predominantly focuses on the stria terminalis and medial forebrain bundle, the NAc, and the subcallosal cingulate as DBS targets for AN.

\section{Human Studies}

With the frequent overlap between AN, OCD, and major depressive disorder (MDD), there have been case re- 
TABLE 2. Published trials or reports of deep brain stimulation for the treatment of anorexia nervosa in humans

\begin{tabular}{|c|c|c|c|c|c|c|}
\hline $\begin{array}{l}\text { Authors } \\
\& \text { Year }\end{array}$ & Pts & $\begin{array}{l}\text { No. of } \\
\text { Pts }\end{array}$ & $\begin{array}{l}\text { Study } \\
\text { Design }\end{array}$ & Target & Stimulation Parameters & Findings \\
\hline $\begin{array}{l}\text { Israël et al., } \\
\quad 2010\end{array}$ & $\begin{array}{l}\text { Adult w/ restric- } \\
\text { tive AN }\end{array}$ & 1 & $\begin{array}{l}\text { Case } \\
\text { report }\end{array}$ & $\begin{array}{l}\text { Subgenual } \\
\text { cingulate }\end{array}$ & $\begin{array}{r}\text { Rt-sided intermittent, } 2 \\
\text { mins on, } 1 \text { min off, } 5 \\
\mu \mathrm{A}, 91 \mu \mathrm{sec}, 130 \mathrm{~Hz}\end{array}$ & $\begin{array}{l}\text { Maintained BMI greater than } 19.1 \text { for } 2 \text { yrs \& } \\
\text { required no further interventions for AN }\end{array}$ \\
\hline $\begin{array}{r}\text { Lipsman et } \\
\text { al., } 2013\end{array}$ & $\begin{array}{l}\text { Adults } w / \\
\text { treatment- } \\
\text { refractory AN }\end{array}$ & 6 & $\begin{array}{l}\text { Open-label } \\
\text { trial }\end{array}$ & $\begin{array}{r}\text { Subcallosal } \\
\text { cingulate }\end{array}$ & $\begin{array}{l}\text { Bilat, 5-7 V, } 90 \mu \mathrm{sec} \\
\qquad 130 \mathrm{~Hz}\end{array}$ & $\begin{array}{l}\text { Acceptable safety profile, } 3 / 6 \text { pts maintained BMI } \\
\text { greater than baseline at } 9 \text { mos, } 3 / 6 \text { pts reported } \\
\text { improved quality of life, } 1 \text { adverse event (sei- } \\
\text { zure) }\end{array}$ \\
\hline $\begin{array}{l}\text { Wang et al., } \\
2013\end{array}$ & $\begin{array}{l}\text { Adults w/ intrac- } \\
\text { table AN }\end{array}$ & 2 & $\begin{array}{l}\text { Case } \\
\text { series }\end{array}$ & $\begin{array}{r}\text { Nucleus ac- } \\
\text { cumbens }\end{array}$ & $\begin{array}{l}\text { Bilat, } 2.5-3.8 \mathrm{~V}, 120-210 \\
\quad \mu s e c, 135-185 \mathrm{~Hz}\end{array}$ & $\begin{array}{l}\text { Improved BMI at } 1 \text { yr postop, no adverse effects } \\
\text { reported }\end{array}$ \\
\hline $\begin{array}{l}\text { Wu et al., } \\
2013\end{array}$ & $\begin{array}{l}\text { Adolescents w/ } \\
\text { treatment- } \\
\text { refractory AN }\end{array}$ & 4 & $\begin{array}{l}\text { Open-label } \\
\text { trial }\end{array}$ & $\begin{array}{r}\text { Nucleus ac- } \\
\text { cumbens }\end{array}$ & $\begin{array}{l}\text { Bilat, } 6 \mathrm{~V}, 90 \mu \mathrm{sec}, 180 \\
\qquad \mathrm{~Hz}\end{array}$ & $\begin{array}{l}\text { Significant increase in BMI in all } 4 \text { pts, w/ average } \\
\text { of } 65 \% \text { increase in body weight }\end{array}$ \\
\hline $\begin{array}{l}\text { Lipsman et } \\
\text { al., } 2017\end{array}$ & $\begin{array}{l}\text { Adults } w / \\
\text { treatment- } \\
\text { refractory AN }\end{array}$ & 16 & $\begin{array}{l}\text { Open-label } \\
\text { trial }\end{array}$ & $\begin{array}{r}\text { Subcallosal } \\
\text { cingulate }\end{array}$ & $\begin{array}{l}\text { Bilat, } 5-6.5 \mathrm{~V}, 90 \mu \mathrm{sec} \\
\qquad 130 \mathrm{~Hz}\end{array}$ & $\begin{array}{l}\text { Significant improvement in mean BMI, depression, } \\
\text { anxiety, affective regulation; long-term changes } \\
\text { in cerebral glucose metabolism }\end{array}$ \\
\hline
\end{tabular}

ports in the medical literature reporting on AN outcomes after DBS for OCD or MDD. McLaughlin et al.$^{39}$ reported the case of a woman with refractory OCD and AN who underwent DBS of the ventral capsule and ventral striatum. With high-frequency stimulation, the patient reported subjective improvement in her AN symptoms. Blomstedt et al. ${ }^{6}$ reported on a woman with MDD and concurrent AN who underwent DBS of the bed nucleus of the stria terminalis. The patient demonstrated no change in BMI, but experienced subjective improvement in food and eating anxiety.

Other reports have focused on DBS specifically for the treatment of AN (Table 2).29,36,37,59,63 Wang et al. ${ }^{59}$ evaluated 2 patients with intractable AN who underwent bilateral NAc DBS. Both patients demonstrated an increase in BMI over the 1-year course of postoperative follow-up while demonstrating no significant adverse effects. Additionally, Israël et al. ${ }^{29}$ published a case report describing a woman with chronic recurrent depression and restrictive AN who underwent bilateral DBS electrode placement in the subgenual cingulate area. Stimulation parameters were adjusted during a hospital stay for a relapse, and eventually intermittent stimulation of the right electrode was determined to be optimal. These stimulation parameters resulted in the patient requiring no further interventions or hospitalizations for AN over the 2-year follow-up period.

In 2013, Lipsman et al. ${ }^{37}$ reported on the first Phase 1 trial of DBS of the subcallosal cingulate gyrus, specifically for treatment-refractory AN in 6 patients. Their results demonstrated an acceptable safety profile, with only 1 patient having a serious adverse event (seizure; Table 2). After 9 months at high-frequency stimulation, 3 of the 6 patients maintained a BMI greater than that at baseline. Additionally, 3 patients reported improvements in quality of life..$^{37}$ This study was succeeded by a larger 1 -year follow-up study in 2017 by Lipsman et al. ${ }^{36}$ involving 16 patients with treatment-refractory AN who underwent the same procedure (Table 2). With chronic stimulation, the patients in that study demonstrated a significant increase in average BMI, from 13.83 to 17.34. The authors found that DBS of the subcallosal cingulate was associated with significant improvements in depression, anxiety, and affective regulation. Additionally, changes in glucose metabolism on PET imaging were detected in the subcallosal and anterior cingulate, parietal lobe, and other regions of the brain associated with dysfunction in AN at 6 and 12 months of stimulation. ${ }^{36} \mathrm{Wu}$ et al ${ }^{63}$ also examined the effects of DBS in 4 patients with AN, but they used the NAc as their stimulation target (Table 2). They reported a mean increase of $65 \%$ in body weight in their patients $(n=4)$ after chronic high-frequency stimulation at a mean followup of 38 months. Further studies are needed to determine the long-term effects and durability of DBS for AN.

\section{Conclusions}

DBS has proven to be a safe, reversible, and highly efficacious treatment for a variety of neurological disorders, and it has been proposed as a treatment for refractory obesity and AN. Studies have demonstrated several potential central nervous system DBS targets for both disorders. The VMH, LH, and NAc have all been demonstrated to have elements of success as DBS targets in animal models of refractory obesity. One open-label trial of 3 patients undergoing LH DBS for refractory obesity has been performed; no serious adverse effects were found, and studies are ongoing to evaluate its effect on obesity. ${ }^{61}$ Larger studies examining the effects of DBS on these separate targets for refractory obesity are needed going forward. AN research has predominantly focused on the stria terminalis and medial forebrain bundle, the subcallosal cingulate, and the NAc as potential DBS targets. The largest trial, involving 16 patients undergoing DBS of the subcallosal cingulate for $\mathrm{AN}$, demonstrated significant improvement in BMI and other psychological outcomes. ${ }^{36}$ These outcomes highlight the promise of DBS for the treatment of refractory AN, but further studies are needed to continue to elucidate its effects and long-term outcomes. 


\section{Acknowledgments}

We thank the staff of Neuroscience Publications at Barrow Neurological Institute for assistance with manuscript preparation.

\section{References}

1. American Psychiatric Association: Diagnostic and Statistical Manual of Mental Disorders, ed 5. Washington, DC: American Psychiatric Association, 2013

2. Anand BK, Brobeck JR: Localization of a "feeding center" in the hypothalamus of the rat. Proc Soc Exp Biol Med 77:323-324, 1951

3. Arcelus J, Mitchell AJ, Wales J, Nielsen S: Mortality rates in patients with anorexia nervosa and other eating disorders: a meta-analysis of 36 studies. Arch Gen Psychiatry 68:724731, 2011

4. Ben-Tovim DI, Walker K, Gilchrist P, Freeman R, Kalucy $\mathrm{R}$, Esterman A: Outcome in patients with eating disorders: a 5-year study. Lancet 357:1254-1257, 2001

5. Bittencourt JC, Presse F, Arias C, Peto C, Vaughan J, Nahon JL, et al: The melanin-concentrating hormone system of the rat brain: an immuno- and hybridization histochemical characterization. J Comp Neurol 319:218-245, 1992

6. Blomstedt P, Naesström M, Bodlund O: Deep brain stimulation in the bed nucleus of the stria terminalis and medial forebrain bundle in a patient with major depressive disorder and anorexia nervosa. Clin Case Rep 5:679-684, 2017

7. Buchwald H, Avidor Y, Braunwald E, Jensen MD, Pories W, Fahrbach K, et al: Bariatric surgery: a systematic review and meta-analysis. JAMA 292:1724-1737, 2004

8. Cederlöf M, Thornton LM, Baker J, Lichtenstein P, Larsson H, Rück C, et al: Etiological overlap between obsessive-compulsive disorder and anorexia nervosa: a longitudinal cohort, multigenerational family and twin study. World Psychiatry 14:333-338, 2015

9. Chang SH, Stoll CR, Song J, Varela JE, Eagon CJ, Colditz GA: The effectiveness and risks of bariatric surgery: an updated systematic review and meta-analysis, 2003-2012. JAMA Surg 149:275-287, 2014

10. Cox JE, Powley TL: Intragastric pair feeding fails to prevent VMH obesity or hyperinsulinemia. Am J Physiol 240:E566-E572, 1981

11. Deutch AY, Cameron DS: Pharmacological characterization of dopamine systems in the nucleus accumbens core and shell. Neuroscience 46:49-56, 1992

12. Ellison Z, Foong J, Howard R, Bullmore E, Williams S, Treasure J: Functional anatomy of calorie fear in anorexia nervosa. Lancet 352:1192, 1998

13. Elmquist JK, Elias CF, Saper CB: From lesions to leptin: hypothalamic control of food intake and body weight. Neuron 22:221-232, 1999

14. Fenoy AJ, Simpson RK Jr: Risks of common complications in deep brain stimulation surgery: management and avoidance. J Neurosurg 120:132-139, 2014

15. Fichter MM, Quadflieg N, Hedlund S: Twelve-year course and outcome predictors of anorexia nervosa. Int J Eat Disord 39:87-100, 2006

16. Flegal KM, Kruszon-Moran D, Carroll MD, Fryar CD, Ogden CL: Trends in obesity among adults in the United States, 2005 to 2014. JAMA 315:2284-2291, 2016

17. Folkow B, Rubinstein EH: Behavioural and autonomic patterns evoked by stimulation of the lateral hypothalamic area in the cat. Acta Physiol Scand 65:292-299, 1965

18. Gloy VL, Briel M, Bhatt DL, Kashyap SR, Schauer PR, Mingrone $\mathrm{G}$, et al: Bariatric surgery versus non-surgical treatment for obesity: a systematic review and meta-analysis of randomised controlled trials. BMJ 347:f5934, 2013

19. Groenewegen HJ, Russchen FT: Organization of the efferent projections of the nucleus accumbens to pallidal, hypothalamic, and mesencephalic structures: a tracing and immunohistochemical study in the cat. J Comp Neurol 223:347-367, 1984

20. Halpern CH, Tekriwal A, Santollo J, Keating JG, Wolf JA, Daniels D, et al: Amelioration of binge eating by nucleus accumbens shell deep brain stimulation in mice involves D2 receptor modulation. J Neurosci 33:7122-7129, 2013

21. Hamani C, McAndrews MP, Cohn M, Oh M, Zumsteg D, Shapiro CM, et al: Memory enhancement induced by hypothalamic/fornix deep brain stimulation. Ann Neurol 63:119123,2008

22. Harat M, Rudaś M, Zieliński P, Birska J, Sokal P: Nucleus accumbens stimulation in pathological obesity. Neurol Neurochir Pol 50:207-210, 2016

23. Harrell LE, Decastro JM, Balagura S: A critical evaluation of body weight loss following lateral hypothalamic lesions. Physiol Behav 15:133-136, 1975

24. Harris EC, Barraclough B: Excess mortality of mental disorder. Br J Psychiatry 173:11-53, 1998

25. Herberg LJ, Blundell JE: Lateral hypothalamus: hoarding behavior elicited by electrical stimulation. Science 155:349350,1967

26. Hetherington AM, Ranson SW: Hypothalamic lesions and adiposity in the rat. Anat Rec 78:149-172, 1940

27. Ho AL, Sussman ES, Zhang M, Pendharkar AV, Azagury $\mathrm{DE}$, Bohon C, et al: Deep brain stimulation for obesity. Cureus $7: \mathrm{e} 259,2015$

28. Hoek HW, van Hoeken D: Review of the prevalence and incidence of eating disorders. Int J Eat Disord 34:383-396, 2003

29. Israël M, Steiger H, Kolivakis T, McGregor L, Sadikot AF: Deep brain stimulation in the subgenual cingulate cortex for an intractable eating disorder. Biol Psychiatry 67:e53-e54, 2010

30. Kaye WH, Wagner A, Fudge JL, Paulus M: Neurocircuity of eating disorders. Curr Top Behav Neurosci 6:37-57, 2011

31. Keesey RE, Powley TL: Self-stimulation and body weight in rats with lateral hypothalamic lesions. Am J Physiol 224:970-978, 1973

32. Kelley AE, Stinus L: Disappearance of hoarding behavior after 6-hydroxydopamine lesions of the mesolimbic dopamine neurons and its reinstatement with L-dopa. Behav Neurosci 99:531-545, 1985

33. Kenny PJ: Reward mechanisms in obesity: new insights and future directions. Neuron 69:664-679, 2011

34. Kupsch A, Benecke R, Müller J, Trottenberg T, Schneider $\mathrm{GH}$, Poewe W, et al: Pallidal deep-brain stimulation in primary generalized or segmental dystonia. N Engl J Med 355:1978-1990, 2006

35. Laćan G, De Salles AA, Gorgulho AA, Krahl SE, Frighetto L, Behnke EJ, et al: Modulation of food intake following deep brain stimulation of the ventromedial hypothalamus in the vervet monkey: laboratory investigation. J Neurosurg 108:336-342, 2008

36. Lipsman N, Lam E, Volpini M, Sutandar K, Twose R, Giacobbe P, et al: Deep brain stimulation of the subcallosal cingulate for treatment-refractory anorexia nervosa: 1 year follow-up of an open-label trial. Lancet Psychiatry 4:285294, 2017

37. Lipsman N, Woodside DB, Giacobbe P, Hamani C, Carter JC, Norwood SJ, et al: Subcallosal cingulate deep brain stimulation for treatment-refractory anorexia nervosa: a phase 1 pilot trial. Lancet 381:1361-1370, 2013

38. Mantione M, van de Brink W, Schuurman PR, Denys D: Smoking cessation and weight loss after chronic deep brain stimulation of the nucleus accumbens: therapeutic and research implications: case report. Neurosurgery 66:E218, 2010 
39. McLaughlin NC, Didie ER, Machado AG, Haber SN, Eskandar EN, Greenberg BD: Improvements in anorexia symptoms after deep brain stimulation for intractable obsessive-compulsive disorder. Biol Psychiatry 73:e29-e31, 2013

40. Melega WP, Laćan G, Gorgulho AA, Behnke EJ, De Salles AA: Hypothalamic deep brain stimulation reduces weight gain in an obesity-animal model. PLoS One 7:e30672, 2012

41. Mendelson J, Chorover SL: Lateral hypothalamic stimulation in satiated rats: T-maze learning for food. Science 149:559561,1965

42. Montemurro DG, Stevenson JA: The localization of hypothalamic structures in the rat influencing water consumption. Yale J Biol Med 28:396-403, 1955

43. Ng M, Fleming T, Robinson M, Thomson B, Graetz N, Margono $\mathrm{C}$, et al: Global, regional, and national prevalence of overweight and obesity in children and adults during 19802013: a systematic analysis for the Global Burden of Disease Study 2013. Lancet 384:766-781, 2014

44. Ogden CL, Carroll MD, Kit BK, Flegal KM: Prevalence of childhood and adult obesity in the United States, 2011-2012. JAMA 311:806-814, 2014

45. Penicaud L, Larue-Achagiotis C, Le Magnen J: Endocrine basis for weight gain after fasting or VMH lesion in rats. Am J Physiol 245:E246-E252, 1983

46. Qu D, Ludwig DS, Gammeltoft S, Piper M, Pelleymounter MA, Cullen MJ, et al: A role for melanin-concentrating hormone in the central regulation of feeding behaviour. Nature 380:243-247, 1996

47. Rehncrona S, Johnels B, Widner H, Törnqvist AL, Hariz M, Sydow O: Long-term efficacy of thalamic deep brain stimulation for tremor: double-blind assessments. Mov Disord 18:163-170, 2003

48. Rui L: Brain regulation of energy balance and body weight. Rev Endocr Metab Disord 14:387-407, 2013

49. Saddoris MP, Cacciapaglia F, Wightman RM, Carelli RM: Differential dopamine release dynamics in the nucleus accumbens core and shell reveal complementary signals for error prediction and incentive motivation. J Neurosci 35:11572-11582, 2015

50. Sakurai T, Amemiya A, Ishii M, Matsuzaki I, Chemelli RM, Tanaka H, et al: Orexins and orexin receptors: a family of hypothalamic neuropeptides and $\mathrm{G}$ protein-coupled receptors that regulate feeding behavior. Cell 92:573-585, 1998

51. Sani S, Jobe K, Smith A, Kordower JH, Bakay RA: Deep brain stimulation for treatment of obesity in rats. J Neurosurg 107:809-813, 2007

52. Schaltenbrand G, Wahren W, Hassler R: Atlas for stereotaxy of the human brain, in: Atlas for Stereotaxy of the Human Brain, ed 2. Stuttgart: Thieme, 1977, p 84

53. Smink FR, van Hoeken D, Hoek HW: Epidemiology of eating disorders: incidence, prevalence and mortality rates.

Curr Psychiatry Rep 14:406-414, 2012

54. Stoeckel LE, Weller RE, Cook EW III, Twieg DB, Knowlton RC, Cox JE: Widespread reward-system activation in obese women in response to pictures of high-calorie foods. Neuroimage 41:636-647, 2008

55. Taghva A, Corrigan JD, Rezai AR: Obesity and brain addic- tion circuitry: implications for deep brain stimulation. Neurosurgery 71:224-238, 2012

56. Torres N, Chabardes S, Piallat B, Devergnas A, Benabid AL: Body fat and body weight reduction following hypothalamic deep brain stimulation in monkeys: an intraventricular approach. Int J Obes 36:1537-1544, 2012

57. Twig G, Yaniv G, Levine H, Leiba A, Goldberger N, Derazne $\mathrm{E}$, et al: Body-mass index in 2.3 million adolescents and cardiovascular death in adulthood. N Engl J Med 374:2430 2440, 2016

58. Uher R, Murphy T, Brammer MJ, Dalgleish T, Phillips ML, Ng VW, et al: Medial prefrontal cortex activity associated with symptom provocation in eating disorders. Am J Psychiatry 161:1238-1246, 2004

59. Wang J, Chang C, Geng N, Wang X, Gao G: Treatment of intractable anorexia nervosa with inactivation of the nucleus accumbens using stereotactic surgery. Stereotact Funct Neurosurg 91:364-372, 2013

60. Weaver FM, Follett K, Stern M, Hur K, Harris C, Marks WJ $\mathrm{Jr}$, et al: Bilateral deep brain stimulation vs best medical therapy for patients with advanced Parkinson disease: a randomized controlled trial. JAMA 301:63-73, 2009

61. Whiting DM, Tomycz ND, Bailes J, de Jonge L, Lecoultre V, Wilent B, et al: Lateral hypothalamic area deep brain stimulation for refractory obesity: a pilot study with preliminary data on safety, body weight, and energy metabolism. J Neurosurg 119:56-63, 2013

62. Wu H, Miller KJ, Blumenfeld Z, Williams NR, Ravikumar VK, Lee KE, et al: Closing the loop on impulsivity via nucleus accumbens delta-band activity in mice and man. Proc Natl Acad Sci U S A 115:192-197, 2018

63. Wu H, Van Dyck-Lippens PJ, Santegoeds R, van Kuyck K, Gabriëls L, Lin G, et al: Deep-brain stimulation for anorexia nervosa. World Neurosurg 80:29.e1-29.e10, 2013

64. Zhang HW, Li DY, Zhao J, Guan YH, Sun BM, Zuo CT: Metabolic imaging of deep brain stimulation in anorexia nervosa: a 18F-FDG PET/CT study. Clin Nucl Med 38:943-948, 2013

\section{Disclosures}

The authors report no conflict of interest concerning the materials or methods used in this study or the findings specified in this paper.

\section{Author Contributions}

Conception and design: all authors. Acquisition of data: all authors. Analysis and interpretation of data: all authors. Drafting the article: all authors. Critically revising the article: all authors. Reviewed submitted version of manuscript: all authors. Statistical analysis: all authors. Administrative/technical/material support: all authors. Study supervision: DM Whiting, AC Whiting.

\section{Correspondence}

Donald M. Whiting: Allegheny General Hospital, Pittsburgh, PA. donald.whiting@ahn.org. 